\title{
European labour market policies in (the) crisis
}

Jochen Clasen, Daniel Clegg and Jon Kvist

Working Paper 2012.12

etul. 


\section{European labour market policies in (the) crisis}

Jochen Clasen, Daniel Clegg and Jon Kvist

Working Paper 2012.12

european trade union institute 
Brussels, 2012

Publisher: ETUI aisbl, Brussels

All rights reserved

Print: ETUI Printshop, Brussels

D/2012/10.574/43

ISSN: 1994-4446 Print

ISSN: 1994-4454 Online

The ETUI is financially supported by the European Union. The European Union is not responsible for any use made of the information contained in this publication. 


\section{Contents}

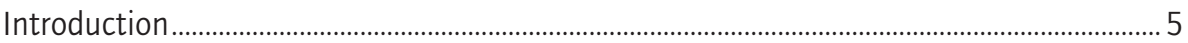

1. The economic crisis and labour market policy: alternative scenarios ..................................

2. Labour market policy responses to the crisis in six European countries ........................ 11

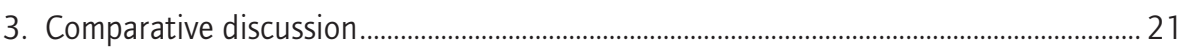

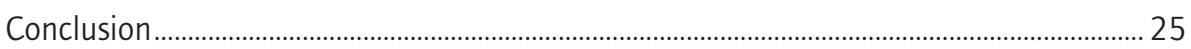

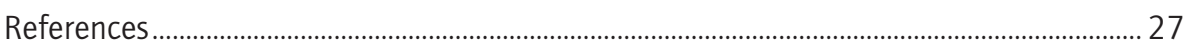





\section{Introduction}

Before the onset of the global economic crisis in 2008, the new millennium had been characterised by the gradual emergence of a new consensus around labour market policy reform in Europe. While in earlier decades labour market policy debates often opposed supporters and opponents of all forms of public intervention in labour markets, by the 2000s there was increasingly widespread coalescence around a more nuanced 'recalibration' agenda, in which the central aim was reworking the precise mix of labour market policies and institutions to best reconcile economic competitiveness and social solidarity and to share the risks and opportunities of modern labour markets more equitably than in the past. The 'flexicurity' debate emphasised protecting individuals through good unemployment benefits and active labour market policies (ALMP) rather than protecting jobs through the strict regulation of employment (Viebrock and Clasen, 2009), while reforms to unemployment benefit systems and ALMPs themselves increasingly sought to extend these measures to those most distant from the labour market (Clasen and Clegg, 2011). In general, ensuring that labour market policies and institutions combated, rather than reinforced, segmentation in the labour market became the overriding concern of policy debates and reforms in many European countries.

This focus on combating labour market segmentation, rather than expanding or cutting labour market policies per se, developed in a period of relatively buoyant economic and employment performance in many countries, at least by post-oil crisis standards. Since 2008, however, this still fragile consensus around the goals of labour market policy reform has been confronted to an entirely novel set of economic circumstances, as a result of sharp drops in output, spikes in unemployment and, as a second-order effect, soaring public deficits. Comparing labour market policy responses to the economic crisis in six European countries, this paper explores how the economic and political challenges of the 'Great Recession' have impacted on the labour market policy reform agenda in Europe. Have recalibration agendas in labour market policy survived, or even been reinforced by, the economic crisis? Or has the crisis on the contrary revived reform logics and debates that seemed to have been surpassed earlier in the decade? Is the economic crisis, in other words, also provoking a crisis for European labour market policy reform?

The first section of the paper briefly outlines a number of analytically distinct patterns of possible labour market policy response to the crisis, and their un- 
derlying political and economic logics. Section 2 then provides sketches of the main labour market policy developments in 6 European countries since the onset of the economic crisis, which are then summarized and compared with reference to the analytical framework in section 3. A brief conclusion draws out the implications of the analysis for the future of labour market policy in Europe. 


\section{The economic crisis and labour market policy: alternative scenarios}

The impact of the economic crisis on employment and unemployment has been strongly mediated by domestic labour market policies and institutions (Leschkeand Watt, 2010). The crisis, however, can also be expected to haveled to the adjustment of these very institutions and policies (Chung and Thewissen, 2011; Vis et al. 2010). Instead of one single possible labour market policy reaction to the crisis, however, a number of different response patterns can be envisaged, depending on the interpretation by domestic political actors of the crisis and their hierarchical ordering of the economic problems and political risks associated with it (Farnsworth and Irving, 2011). The 'crisis narrative' that dominates is thus important, and the competition between narratives or frames is an inherently political process (Boin et al., 2009; Kuipers, 2006). We label what we see as the main interpretative frames for the current economic crisis as 'crisis as demand shock', 'crisis as fiscal emergency' and 'crisis as structural challenge'. As detailed below, each of these would be associated with rather different labour market policy response patterns.

Crisis as demand shock: In the face of a massive output shock, there are strong economic arguments for fiscal loosening and expansion of public investment and expenditure. Temporarily sustaining consumer demand can prevent the emergence of a dangerous recessionary spiral, where gloomy expectations and restrained consumption and investment serve to institutionalise low levels of aggregate demand. The role that labour market policies may play relative to fiscal or monetary policy instruments in such economic stimulus measures can of course vary, though expanded labour market policies in general and improved unemployment benefits in particular are widely recognised to be especially effective economic stabilizers (e.g. Dolls et al., 2009).

Alongside the economic case for such an expansionary labour market policy response pattern, governments may also have strong political incentives for taking this path. Sharp rises in unemployment may increase electoral demands for labour market policies, as previously secure 'insiders' become exposed to economic vulnerability (Rueda, 2007). Moreover, governments with their re-election prospects in mind may well be encouraged to privilege those measures that either reduce or prevent open unemployment, such as shorttime working schemes, large job creation programmes and possibly also the relaxation of conditions for entry to early retirement programmes, as they did widely in the recession of the early 1980s (Bonoli, 2010). Here we see how political considerations may lead to this interpretative frame being deployed 
beyond the limits that would be suggested by economic or efficiency arguments alone. Such considerations might also lead it to being deployed in a selective manner, with expansionary measures being directed only to already relatively better-protected - but also more politically influential - groups in the workforce, for example through the targeting of short-time working measures on firms in heavily unionised sectors. Importantly, this could result in an abandonment of the focus on combating the potentially segmenting effects of labour market policies focused narrowly on the core workforce that has characterised European labour market policy over the last decade.

Crisis as fiscal emergency: A second possible interpretative frame for the crisis has even more sombre implications for the long-term prospects of European labour market policy. In part as a result of fiscal stimulus measures taken in its early stages, as well in many countries of massive investments of public resources in the recapitalisation of the banking sector, the economic crisis has lead to spiralling public debts and deficits across the continent (Leschke et al. 2012). While most would accept the need for deficit reduction in the medium term, it is possible that this issue quickly comes to dominate the policy agenda, and ushers in an era of generalised austerity that impacts particularly seriously in the labour market policy field.

If a bitter competition for increasingly scarce public resources emerges, labour market policies may in effect find themselves particularly exposed and vulnerable. It is well known that, even though the effect may be somewhat moderated by conditions of high unemployment, policies directed to the unemployed do not enjoy the broad public support of health care or education (Svallfors, 2010). The 'there is no alternative' narrative for cuts that high deficits makes possible may thus face less contestation in this policy field than others. Though a depressed labour market makes arguments about 'self-sufficiency' less plausible, and makes cuts to the most visible victims of the crisis seem more unfair, governments that are minded to do so can also possibly stoke resentment towards the 'idle' unemployed at a time when those in work themselves feel vulnerable and are seeing their wages stagnate and working conditions worsen. Additionally, with reference to the future recovery, microeconomic arguments can be mobilised to add an additional layer of justification for cuts to unemployment benefits and the withdrawal of labour market programmes. The crisis may in this way re-energise traditional arguments in favour of across the board cuts in labour market policies, which were common in the 1990s but had been heard less frequently in recent years.

Crisis as structural challenge: A final and rather more optimistic scenario is that the crisis may instead beinterpreted mainly as an opportunity to actually drive forward the recalibration agendas that have dominated labour market policy debates for much of the 2000s, but in many European countries found themselves still blocked by a range of political and institutional obstacles. In the light of economic difficulties and huge public deficits (and conscious of the concerns of rating agencies about issues of long-term competitiveness for the solvency of public accounts), governments may see a heightened urgency to push through reforms that were earlier in the decade promoted as a means 
to better align social protection institutions with the functioning of the contemporary labour market, and create the conditions for participation-led economic growth. Examples of such policies might be package deals that trade improved unemployment benefits and active labour market policies for reductions in employment protection, or parametric reforms extending entitlement to unemployment benefits and ALMPs to precarious workers where they have traditionally been excluded.

To be sure, a major economic crisis is not a self-evidently favourable context for the implementation of potentially unpopular reforms. In a context of generalised insecurity, voters and interest groups that have reservations about the changes proposed may harden their opposition to them, prolonging any stalemate. On the other hand, however, the fact that those - such as temporary employees - with the weakest attachment to the labour market have been hardest hit by the crisis may sensitise policy makers and public opinion alike to their plight. Further, to the extent that past opposition to recalibrating reforms has at times been based less on reasoned calculation of costs and benefits than on institutional and political routines, the disruptive and alarming impacts of a major recession may well open 'windows of opportunity' for change (cf. Castles, 2010). Or to put it in Heclo's (1974) terms, in a time of crisis the conventional forms of 'powering' around policy initiatives may well give way to a 'puzzling' mode of policy development, encouraging actors to make more creative use of institutional and policy resources than in the past.

Table 1 Labour market policy responses to the crisis: three interpretative frames

\begin{tabular}{|c|c|c|c|}
\hline Interpretative frame & 'Crisis as demand shock' & $\begin{array}{l}\text { 'Crisis as fiscal } \\
\text { emergency' }\end{array}$ & $\begin{array}{l}\text { 'Crisis as structural } \\
\text { challenge' }\end{array}$ \\
\hline Economic logic & Prevent recessionary spiral & Reduce public deficits & $\begin{array}{l}\text { Enhance long-term com- } \\
\text { petitiveness }\end{array}$ \\
\hline Political logic & $\begin{array}{l}\text { Increased 'insider' } \\
\text { demand; } \\
\text { Reducing open unemploy- } \\
\text { ment }\end{array}$ & $\begin{array}{l}\text { Preventing tax increases; } \\
\text { Exploiting resentment } \\
\text { towards unemployed }\end{array}$ & $\begin{array}{l}\text { Visibility of 'outsider' } \\
\text { disadvantage; } \\
\text { Disruption of policy } \\
\text { routines; } \\
\text { Crisis and creativity }\end{array}$ \\
\hline $\begin{array}{l}\text { Labour market policy } \\
\text { response }\end{array}$ & $\begin{array}{l}\text { Temporary expansion of } \\
\text { unemployment benefits; } \\
\text { Subsidised short-time } \\
\text { work; } \\
\text { Labour market pro- } \\
\text { grammes; } \\
\text { Early retirement }\end{array}$ & $\begin{array}{l}\text { Retrenchment of unem- } \\
\text { ployment benefits and la- } \\
\text { bour market programmes }\end{array}$ & $\begin{array}{l}\text { Structural expansion of } \\
\text { unemployment benefits } \\
\text { and labour market pro- } \\
\text { grammes; Distributive } \\
\text { recalibration of labour } \\
\text { market policy and regula- } \\
\text { tion }\end{array}$ \\
\hline $\begin{array}{l}\text { Priority target of extra } \\
\text { labour market support }\end{array}$ & Core workforce & Nobody & Peripheral workforce \\
\hline
\end{tabular}


These three interpretative frames, and the labour market policy response patterns that are associated with them, are not necessarily mutually exclusive in a given national context. The economic crisis is objectively multifaceted, confronting policy makers with challenges of different kinds. It is also dynamic, with the purchase that can be achieved by alternative narratives likely to change as the effects of the crisis evolve. However, to the extent that the competition between these interpretative frames is also a fundamentally political process, it is unlikely that the labour market policy response will be determined by cool assessment of the economic context alone, and as much variation would be expected to be visible between countries as across the economic cycle. 


\section{Labour market policy responses to the crisis in six European countries}

To explore this argument, we below examine labour market policy developments in six contrasting European countries since 2008. The cases have been selected to explore that impact of variations in the impact of the economic crisis on the labour market, as well as - and in part in relation to - the range of political economy, welfare state and labour market policy traditions in contemporary Europe.

\section{Czech Republic}

In the Czech Republic the economic crisis was felt relatively late and moderately, at least compared to many neighbouring countries (OECD, 2010a). Nonetheless, real GDP fell by over 4\% in 2009 and in the same year unemployment witnessed its biggest quarterly increase in a decade, jumping to nearly $8 \%$. At the end of 2011 unemployment stood at 6.8\%, more than $40 \%$ higher than four years earlier. Tackling the crisis has been complicated by an unstable political situation. The centre-right government, unpopular due to a raft of liberalising reforms in areas such as pensions and healthcare and lacking a majority in Parliament, lost a vote of confidence in spring 2009, but limped on until elections were eventually called for May 2010. More positively, however, the crisis has generated a series of national level tripartite agreements between the unions, employers associations and the government - a new practice in the Czech context (European Commission, 2010a).

One of the major results of these tripartite deliberations was the introduction of a subsidised short-time working scheme, closely modelled on the German Kurzarbeit (see below). This benefited close to $2 \%$ of the entire Czech workforce in 2009, and somewhat less than half of that in 2010 (Hijzen and Venn, 2011), and is considered to have been significant in preventing unemployment from increasing yet further (OECD 2010b). Also introduced in spring 2009, the Education is a Chance' and 'Educate Yourself' programmes have played a similar role, by providing subsidies to employers to support training activities for their staff that help to maintain their employment. In the case of Educate Yourself' the programme is explicitly limited to companies adversely affected by the economic recession (European Employment Observatory, 2010). Both programmes are to a large extent financed by the European Structural Funds.

While there has therefore been some response to the increased risks being ex- 
perienced by labour market 'insiders', rather little has been done in the Czech Republic for those already unemployed. This is largely in keeping with the recent development of labour market policy in the Czech Republic, which has become increasingly dualistic since the late 1990s (Sirovatka and Hora, 2011). The one measure that has come on stream during the financial crisis to directly support the already unemployed itself manifested this bias to a degree. While unemployment benefit replacement rates were slightly increased (from $50 \%$ to $60 \%$ of the reference salary) for the first two months of unemployment, this was at the expense of the one month reduction in the duration of payment (European Commission, 2010b: 94), meaning that while the shortterm unemployed enjoy better protection, those who remain unemployed for longer will more quickly be forced to rely on the far less generous social assistance benefit.

Improving social assistance was one of the electoral promises of the Czech social democratic party in the 2010 election campaign, but although they gained the highest number of votes the result represented a serious defeat for the centre-left. The election instead resulted in the formation of a new centre right coalition government with an apparent mandate for tough austerity measures in a context of growing concern over public deficits and indebtedness. Such concerns resulted, for example, in a measure reducing labour costs for new hires that was due to run until the end of 2010 being withdrawn early due to fears over its budgetary implications (European Commission, 2010b: 84). While the new government made liberalisation of employment contracts to promote greater flexibility one of its top priorities, it has brought forward no plans to accompany these changes with improvements to either passive or active labour market policies (EIRO, 2010a). On the contrary, when eventually adopted, the coalition's reforms included some modest structural reforms of labour market regulation, but included limitations on unemployment benefit entitlement for voluntary separations and the outright abolitions of some specific benefits for low income families (EIRO, 2011a).

\section{Denmark}

Prior to the onset of the financial crisis a structural reform had been initiated in the Danish public sector, leading to significant changes in the organisation of Danish labour market policy. Most noteworthy was the progressive move to a so-called 'one-stringed' system for all job-seekers, replacing the differentiated system of active labour market policy provision - but not benefit levels - for insured and uninsured jobseekers with a single system run by municipalities (Goul Andersen, 2011). In progress since 2005, the implementation of a single municipal administration was finalised in 2008 an 2009. Though it might in principle reduce segmentation in access to labour market support, this change was motivated more by the right-wing coalition government's desire to weaken the trade unions by undermining the voluntary union-affiliated unemployment insurance funds, presumed important for membership recruitment in Danish unions (Kvist \& Harsløf 2011). 
In October 2008 Denmark recorded its best economic performance for years, with huge labour market shortages. The Minister of Employment boasted that all of the unemployed in Denmark could in principle be seated in the national football arena, while when presenting the Budget Agreement in October 2008 the Minister of Finance jokingly claimed that Denmark could soon buy the rest of the world if business continued in the same favourable way. But soon it was no longer business as usual and the Danish unemployed - who grew as a share of the labour force from 3.1\% in J une 2008 to $7.5 \%$ two years later - could soon fill several football arenas.

As late as in June 2009 the conventional wisdom was however that the crisis would be over soon, with the government's 'Spring Package 2.0' designed to boost employment in the short-term mainly through lower taxes, which disproportionately reduced the tax burden for higher earners. In tandem, continuing concerns over labour shortages saw initiatives aimed at reducing sickness absence, as well as two 'youth packages' targeted on unemployed under the age of 30, and intended to help them find jobs sooner in their unemployment spell through extended activation periods and intensified contact with case workers. In a similar vein, periods of supplementary unemployment insurance - paid to claimants with part-time jobs - were reduced with the intention of motivating recipients to extend their working hours.

As the economic crisis continued and became manifest in rising unemployment and deteriorating public finances, however, the orientation of policy changed. In the Spring of 2010 the government and the Danish People's Party agreed on a 'Recovery Package', which in addition to suspending or postponing some tax relief promised earlier notably included a halving of the maximum unemployment benefit period, from four years to two. Though a two year benefit period remains relatively long by international standards, this move nonetheless constituted a clear break with the existing paradigm of easily accessible unemployment insurance for potentially long periods, one of the foundations of the famed Danish flexicurity model. In May 2010 the government, the Danish Peoples Party and the Social Liberals also agreed on a retirement reform which brought forward the phasing in of gradual increases in the retirement ages in the national old age pension and the voluntary early exit benefit (Efterløn), and also reduced the maximum benefit period of the latter. This reform married the deficit reduction considerations that had dominated the 'Recovery Package' to more structural concerns regarding the need to discourage early retirement in the light of population ageing.

Following elections in September 2011 the Social Democrats formed a new governing coalition with the Socialist Peoples Party and the Social Liberals to end a decade of Liberal-Conservative rule. The new government swiftly removed benefit ceilings that had been placed on social assistance by its predecessor, and also abolished the discriminatory 'Start Help' programme, a less generous form of social assistance for new entrants to the country introduced in 2002. At the demand of their Social Liberal coalition partners, however, the Social Democrats' promise to restore the maximum period of unemployment benefit receipt to four years was not kept. The new govern- 
ment also maintained the previous administration's changes to the early retirement scheme.

In sum, after adopting relatively modest stimulus measures in the first phase of the crisis, buoyed by a belief that it would be short lived and have moderate effects on employment, Danish governments have responded to the reality of its depth and seriousness by adopting labour market policy changes aimed mainly at improving public finances, despite budget deficits turning out to be smaller than initially expected in both 2010 and 2011. The rolling out of a longer-standing structural reform programme has continued through both phases of the crisis response, seeking to reduce remaining segmentation in the labour market as well as to cope with the challenge of population ageing. The crisis has also coincided with the abolition of particularly restrictive policies of social support towards some of those with the weakest attachment to the labour market, though this has resulted more from political changes than from a reaction to the new economic context.

\section{France}

When the economic crisis hit, the centre-right French government was also in the process of implementing a number of high-profile structural reforms to benefit and labour market policies, which had been among the pledges that Nicolas Sarkozy had made in his successful campaign for the Presidency in 2007. The following year thus saw the merger of the unemployment insurance system and the public employment service as well as the fusion of the national social assistance scheme with some existing tax credits to create an 'Active Solidarity Income' (Revenu de Solidarité Active - RSA), a social assistance benefit that can also be received as a permanent in-work subsidy (Clegg, 2011). The implementation of these important reforms has however been complicated by the economic crisis, which saw unemployment increase from $7.7 \%$ in December 2007 to a peak of $10 \%$ in J anuary 2010, a rate at which it has remained broadly stable subsequently.

Alongside the rather effective automatic stabilisation function played by the French welfare system (ILO, 2010), a number of emergency measures adopted by the government have helped to contain the employment effects of the crisis. Most noteworthy among these have been subsidised short-time working (or 'partial unemployment') schemes, for which eligibility conditions were loosened and entitlements enhanced early in the crisis. At their peak in the third quarter of 2009 these schemes concerned around 300,000 workers, and are estimated to have helped preserve some 30,000 jobs (OECD, 2010b). Special professional reinsertion measures for victims of economically-motivated redundancies, combining bespoke employment services and benefit payments well above the level of regular unemployment insurance were also extended to additional employment basins.

While both these measures were directed mainly to the core workforce, the French labour market policy response to the crisis cannot however be re- 
duced to 'insider' protection alone (Gautié, 2011). In 2009 around 500,000 new subsidised employment contracts (contrats aidés) were concluded in the public, para-public and private sectors in 2009, a 40\% increase on 2008 (DARES, 2011). A further $€ 1$ billion package of financial supports for firms recruiting young people on alternating training or apprenticeship contracts was also unveiled in spring 2009. The announcement by Nicolas Sarkozy of the extension of the aforementioned RSA to under-25s later in the same year furthermore opened a breach in the traditional French principle of excluding childless young people from social assistance, even if strict eligibility requirements limit the number of young people who will benefit from this (Clegg and Palier, 2012).

In terms of pursuing an agenda of combating segmentation even in the context of crisis, the measures adopted in France following national inter-professional negotiations are even more striking. The unemployment insurance reform concluded between the social partners in early 2009 represented a first important innovation. Where in the past it was always the benefit rights of those with the shortest contribution records that were the main adjustment variable in the notoriously pro-cyclical pattern of unemployment benefit reform in France, the 2009 agreement on the contrary improved access to insurance benefits for those with limited contribution histories while reducing the duration of benefit payments for some of those with better work records (Clegg, 2011; Corneilleau and Elbaum, 2010). Other agreements between the social partners in 2009 and 2011 also saw bipartite training funds traditionally reserved for training already-employed workers firstly redirected to the unemployed 'most distant from employment' and then used to finance reinforced support to young people through the public employment service (Freyssinet, 2011). Alongside these distributively innovative reforms, the establishment in 2009 of a 'supra-institution' under tripartite governance to pool and coordinate resources flowing from the various tax- and contribution-financed institutions involved in French labour market policy in addition holds the prospect of a considerable enhancement in the institutional capacity for governments to harness and combine diverse financing streams to develop more integrated labour market policies. Though this Fonds d'Investissement Sociale (Fiso) has been created as a temporary cyclical measure, its success might lead to it being made permanent, which would represent a valuable step in the modernisation of French labour market policy (European Employment Observatory, 2010).

As elsewhere, 2010 saw a shift in economic policy priorities from stabilisation to fiscal consolidation in France, with the 2011 budget seeking to reduce the budget deficit from a record $7.7 \%$ in 2010 to 6\% at the end of 2011 and $3 \%$ by 2013, in large part through the non-replacement of around 100,000 public sector posts between 2011 and 2013. Until now, however, the labour market policy budget has been largely spared in this general austerity drive. In tandem with some exceptional expansionary measures, the impact of the economic crisis on French labour market policy has thus primarily been to encourage an apparent deepening of structural reform dynamics that challenge some of its longstanding inequities and institutional gridlocks. 


\section{Germany}

In Germany a structural transformation of labour market policy began in the late 1990s, affecting jobseekers in receipt of unemployment insurance as well as assistance benefits. As discussed elsewhere (Clasen and Goerne, 2011; 2012), the Hartz reforms accelerated the emergence of a new landscape of labour market policy, characterised by a strong emphasis on job search and short training or work-experience courses at the expense of previously prominent qualification and well supported job creation options. German active labour market policy has not only declined as a proportion of GDP over the past ten years, but its overall composition has shifted to a 'work-first' orientation (see OECD, 2011b). At the same time, as part of an institutional integration of previously separate transfer programmes, the Hartz reforms also expanded the reach of labour market policy to (previous) social assistance claimants who hitherto had been almost entirely excluded from federal labour market programmes (Clasen and Goerne, 2011).

By the time the crisis affected the German economy this new institutional architecture was already in place, and was not modified despite a massive decline in economic growth and rising unemployment in 2009. As it turned out, in 2010 the economy actually improved steadily and by early 2011 unemployment had fallen to a level below what is was prior to the crisis. Moreover, while elsewhere in Europe unemployment climbed again in the wake of the financial turmoil and Euro crisis of late 2011, in Germany employment continued to rise and unemployment to fall, reaching as little as 5.5\% in October 2011. This remarkable recovery was to a large degree supported by export-oriented manufacturing. In contrast to the 1980s, companies in the manufacturing sector are facing a demographic decline of trained personnel, and thus had a strong incentive for retaining rather than shedding labour. This explains the popularity of instruments such as industry-wide collective agreements on flexible working time as well as various forms of company-based internal flexibility (Möller, 2010). About one third of all German companies made use of 'working time accounts' to reduce the actual working hours per week in return for 'credits' that have to be worked when businesses pick up again. The fact that these accounts were generally 'in surplus' before the crisis hit made it easier for firms to make use of this instrument (Bogedan et al., 2009).

Labour market policy strongly complemented these instruments. Most notably, employees in companies that reduced weekly working hours for economic reasons made use of extended options for Kurzarbeit (short-time working allowance). Already used in previous downturns, as in the wake of German unification, the allowance replaces individual earnings at a level equivalent to unemployment benefit for the reduced working hours. In response to the crisis the access to the allowance was eased, and fixed-term and temporary agency workers also became eligible. Moreover, the period for which the allowance is payable was extended from initially six to 18 months in 2009, and temporarily even to 24 months. The number of employees in receipt of the allowance quadrupled during 2009 to just over 3\% of the workforce (Möller, 2010; Hijzen and Venn, 2011:18). The improved conditions and the take-up 
of this instrument was one principal reason why the sharp downturn in economic output was not reflected by a concomitant rise in unemployment.

This is not to say that there was no retrenchment. In summer 2010 the centreright/ liberal coalition used fiscal pressures to legitimate cutbacks in labour market policy budgets, resulting in the abolition of parental benefits and pension credits for recipients of unemployment assistance (unemployment benefit II), as well as the temporary allowance for benefit claimants transferring from unemployment insurance to the latter. A series of cutbacks in active programmes was subsequently announced to come into effect between 2011 and 2015, some of which to affect particularly long-term unemployed persons such as job 'integration subsidies' which will no longer be granted as entitlement but be dependent on case managers' discretion. Some retrenchment measures also affected recipients of unemployment insurance, such as the abolition of job creation programmes and cuts to business-start up grants.

In sum, the economic crisis in Germany can be regarded as having triggered two types of policy response. First and most significantly, there was an expansion and heavy use of temporary instruments aimed at retaining workers and avoiding unemployment, followed by a round of retrenchment in benefit provision for long-term unemployed, and subsequently in active labour market schemes. While this pattern bears some similarities to earlier policy patterns at times of tight public budgets, such as in the early 1980s (Clasen, 2005), the most recent series of cutbacks has not challenged the greater institutional integration of labour market policy after the mid 2000s, which extended the reach of active programmes to formerly excluded social assistance claimants - even though the scope of these programmes has been considerably scaled down in recent years.

\section{Spain}

After a long period of sustained economic and employment growth, the Spanish labour market was hit extremely hard by the economic crisis, with unemployment doubling in a year and reaching $20 \%$ of the labour force by early 2010. It has continued to rise more slowly subsequently, standing at around $23 \%$ by the end of 2011, and nearly $50 \%$ for young people. Though the output shock in Spain was not unusually large, its impact on employment and unemployment was (Leschke and Watt, 2010). This was in part the result of the heavy reliance of the Spanish economy on the low productivity, labour intensive construction sector, in which employment collapsed when the real estate bubble burst. But it was also a consequence of some specific institutional features of the Spanish labour market, such as relatively rigid wage-setting procedures and the extremely heavy use of fixed-term contracts due to high separation costs for permanent employees (ibid; Wölfl and Mora-Sanguinetti, 2011). While the total numbers of employees on permanent contacts remained very stable between 2007 and 2010, the number of employees on temporary contracts fell by nearly $30 \%$.

The initial response of the Socialist-led government coalition, re-elected fol- 
lowing elections in March 2008, was broadly Keynesian. The $€ 11$ billion, 2 year, 'plan E' stimulus package adopted in late 2008 contained a number of measures to directly support employment, most notably funds for local authorities to organise programmes of public works, but also measures more closely targeted on the unemployed such as social security rebates for employers hiring specific categories of unemployed workers and the recruitment of additional manpower in the public employment services. This plan E also included some expanded early retirement provision and an equivalent shorttime working measure (the ERE), and in 2009 Parliament also approved a new $€ 420$ monthly unemployment benefit for those who, after J anuary 2009, had exhausted their entitlement to unemployment insurance or assistance (EIRO, 2009). The government limited the duration of entitlement to this benefit to 180 days, but included a provision that it would be extended if the unemployment rate remained at or above $17 \%$, a provision that triggered two extensions in 2010.

With the Spanish public sector deficit over 11\% of GDP at the end of 2009, and solvency ratings for Spain's public accounts being reduced amidst rumours of an IMF bail-out, the government changed course in 2010, announcing a series of austerity measures, including tax rises and public expenditure cuts. Labour market policy budgets were, however, relatively spared, with cuts concentrated instead on public sector pay, pensions, healthcare and family policy (EIRO, 2010b). Though it was announced in December 2010 that the exceptional unemployment benefit would not - despite unemployment remaining over the crucial $17 \%$ rate - be extended for a third time, this measure was replaced in the tripartite social pact signed in February 2011 by an exceptional unemployment benefit of near equivalent value (€400), accompanied by a mandatory professional requalification programme (EIRO, 2011b). This measure was further extended by the conservative government of Mariano Rajoy after their election in November 2011, despite an aggressive acceleration of the austerity drive in many other areas.

Rather than cuts, Spanish governments - first socialist, then conservative have focused most of their labour market policy energies in the second phase of the crisis on more structural labour market reforms. After the failure of repeated rounds of negotiations between the social partners, in J une 2010 the Zapatero government presented proposals for the reform of collective bargaining and employment regulation. Regarding the latter, the government reduced severance pay entitlements for employees on permanent contracts and increased them for those on temporary contracts, while simultaneously introducing a system of individually capitalised mobility-funds, closely modelled on the much-vaunted reform Austrian system. In reforms announced in February 2012, after yet further failed negotiations between the social partners, the Rajoy government further deepened these measures, proposing an even more stark reduction in severance pay for permanent employees and making it illegal to extend temporary contracts more than once. Along flexicurity lines, these changes in employment regulation have been complemented by other changes in labour market policy, such as the redirection of previously ineffective recruitment subsidies to the most vulnerable groups among the 
unemployed, and the legalisation of private employment agencies from December 2010. In the tripartite social pact that was - somewhat surprisingly, in view of the poor relationship between governments and the unions since early 2010 - agreed in February 2011, a 'modernising compromise' was struck that traded investments in ALMP and some temporary unemployment benefit measures against significant pension retrenchment, including progressive increase in the retirement age, a restriction of early retirement and a change in the basis for calculating pension entitlements (EIRO, 2011b).

The Spanish labour market policy reaction to the economic crisis thus follows a distinctly two-stage pattern, with initial expansionary measures giving ground to a new strategy as public sector deficits have mounted and international pressure on the Spanish government has increased. In the second phase, however, the labour market policy agenda has not been one dominated by cuts, but rather by issues of structural reforms seeking to address some long-acknowledged weaknesses of the Spanish employment model. While it is difficult to assess how far these reforms - which have provoked considerable protest - will address the strong duality of the Spanish labour market (Wölfl and Mora-Sanguinetti, 2011), they do represent a breakthrough in a field where major distributive recalibration has been hindered by institutional and political blockages for decades.

\section{United Kingdom}

Since the mid 1990s both major political parties in the UK have supported the notion that a liberal and deregulated labour market offers the country a competitive advantage in a more globalised economy. As a consequence, British labour market policy has increasingly been dominated by job search and 'work-first' approaches at the expense of any emphasis on training or job creation. Britain also has one of the least generous unemployment benefit systems in the developed world (Clegg, 2010). In the new millennium, reform efforts have concentrated on fine-tuning this policy framework, but also expanding its reach beyond the unemployed in the narrow sense, notably through the institutional integration of benefit and service provision for different groups of working age people (Clasen, 2011). This agenda has continued in the current crisis, with the coalition government elected in 2010 introducing high-profile reforms of welfare-to-work provision (the 'Work Programme') and announcing an amalgamation, from 2013, of means-tested transfers for all people of working age (the so-called 'Universal Credit'). While this doesn't represent a notable departure from the existing structural reform trajectory in British labour market policy, it does deepen it.

Against the background of a negative trade balance since the mid 1990s (Fender, 2010), British economic growth prior to 2008 was based on high levels of consumer debt and bank lending in the context of a long-term trend of rising house prices. The financial crisis thus had a direct and immediate impact on the UK economy, only partly mitigated by massive bail-outs of financial institutions. While a relatively sharp economic contraction did not cause 
unemployment in the UK to rise as steeply as anticipated in some quarters, unemployment nonetheless increased steadily from 5.1\% at the end of 2007 to nearly $8 \%$ in the middle of 2009, before stabilising. Although labour market measures played a smaller role in Britain's economic stimulus package than in those of many other countries (Clegg, 2010), some contra-cyclical labour market policies were implemented in response to this, most notably the Future J obs' fund, which guaranteed those under the age of 25 (and in receipt of benefits for six months) employment, training or work experience. This measure was announced in anticipation of rising unemployment especially among younger people, a typical feature of previous recessions in the UK.

The abolition of the Future J obs' fund in 2010 can be seen as the beginning of a second phase of labour market policy, which has unfolded under a conservative/ liberal coalition government elected in May that year. In a context where the scale of the UK's public deficit increasingly dominated policy making debates, the new government committed itself to reducing public spending more rapidly and more radically than its predecessor had been planned. Other targets for retrenchment consisted of public services and transfer programmes (Taylor-Gooby and Stoker, 2011). Typically dependent not only on unemployment benefit but also a range of other transfers (Clasen, 2009), British jobseekers were affected by a number of direct and indirect cutbacks in the areas of housing benefit, child benefit and local tax benefits. In addition jobseekers were subjected to a further tightening of benefit conditionality and sanctions directed at those who refused to accept work placements or job offers.

In the middle of 2011 unemployment began rising again in the UK, approaching $8.5 \%$ by the end of the year. More significantly, youth unemployment increased to over $20 \%$, and in absolute terms passed over the symbolically significant level of 1 million. In part as a result of pressure from the smaller party in the governing coalition, this trend led to a partial reversal of the earlier policy cutbacks in active labour market policy, illustrated first by an increase in the number of publicly funded apprenticeships and work placement schemes, and then by the announcement of a new 'Youth Contract', which from April 2012 provides subsidies to employers taking on young unemployed people for 6 months, and will on government estimates create 400,000 opportunities for young unemployed people. While the total cost of this measure is equivalent to the 'Future J obs' fund, it will however be met not from new resources but instead from the reallocation of existing expenditure, including additional cuts to in-work support for low paid families.

Despite already operating at a lower level of expenditure compared with other major European countries, the British policy response therefore contained initially, and to a lesser extent latterly - only modest attempts to cushion the unemployed from the effects of the crisis. Much more dominant under the current government is the explicit use of the crisis as justification for a wave of retrenchment measures, many of which have affected job seekers. The longerstanding trajectory in British labour market policy has not been derailed by the crisis, and has to a certain degree even progressed in it, but is as a result taking on an even leaner character than in the past. 


\section{Comparative discussion}

This brief sketch of labour market policy responses to the economic crisis in six European countries since 2008 reveals some similarities in national response patterns, as well as some interesting differences. Regarding the former, it is evident that in all countries the reaction to crisis has unfolded in two main phases. In all the cases we analysed, as indeed in others, the initial response to the crisis was broadly in line with an interpretative frame that we called 'crisis as demand shock'. The overall orientation was not at this time to cut back spending on labour market policy, but instead to use it to cushion the effects of the crisis on labour markets and workers (see also Vis et al. 2010). Everywhere, too, this expansionary response has subsequently been at least tempered by a growing focus on public finance concerns, which have continued to preoccupy political leaders even as Europe's economies headed back towards recession in 2011. A further noteworthy similarity across the cases is that early retirement policies were a very minimal part of the labour market policy repertoire that was deployed in this crisis, even in the initial expansionary phase of the reaction to it. Indeed, in some countries - notably Denmark - such measures have been scaled back during the crisis. Unlike in the 1980s, when many public and corporatist policies were aimed at labour shedding, a common denominator in response to the recent crisis has been the aim of keeping workers in, or connected to, employment.

These fairly evident commonalities should however not deflect attention from the significant differences in national labour market policy responses to the crisis that are also revealed by our analysis. These differences concern the intensity of initial expansionary measures and the subsequent cuts, as well as the targeting of the benefits of expansion and the burdens of cuts on different groups in the labour market, which both vary significantly across the cases we have discussed above. With reference to the distinct dimensions, it is possible in summary to identify three distinctive patterns of labour market policy response to the crisis that can be related to distinctive combinations of interpretative frames (Table 2).

A first configuration is represented by the cases of the Czech Republic and Germany. In both, the initial expansionary response to the crisis was significant in scale. What distinguished these cases in the initial phase of the crisis from France and Spain - where a similarly energetic labour market policy response was witnessed - was the heavy use of both statutory and (in the German case) non-statutory labour market policies to adjust the work- 
Table 2 Patterns of labour market policy response to the economic crisis in Europe

\begin{tabular}{llll} 
Interpretative frame & 'Crisis as demand shock' & $\begin{array}{l}\text { 'Crisis as fiscal } \\
\text { emergency' }\end{array}$ & $\begin{array}{l}\text { 'Crisis as structural } \\
\text { challenge' }\end{array}$ \\
\hline Czech Republic & ++ & ++ & $/$ \\
Germany & ++ & ++ & $/$ \\
\hline Denmark & + & ++ & + \\
\hline United Kingdom & + & ++ & ++ \\
\hline France & ++ & + & ++ \\
\hline Spain & ++ & + & +
\end{tabular}

Note: $++=$ major LMP orientation $;+=$ minor LMP orientation; / = not an LMP orientation

ing times, and protect the employment, of already employed 'core' workers, with little effort devoted to better supporting those who did lose their jobs. While these short-time working measures were in the German case at least formally extended to temporary employees and agency workers too, they were overwhelmingly used by large and middle-sized employers in manufacturing to maintain the employment of more qualified staff during the crisis. The Czech and German governments also implemented relatively significant cuts in labour market budgets as concerns about public deficits grew, and in both cases these often either targeted (or indirectly affected) the long-term unemployed. The common overall pattern is thus one of a response to the crisis that has attempted to cushion core workers while cutting a range of programmes and entitlements for the unemployed, with the latter particularly affecting the long-term unemployed.

Denmark and the UK are exemplars of a second distinctive type of labour market policy response. In both countries, labour market measures aimed at cushioning the effects of the crisis were implemented only on a relatively modest scale, albeit for different reasons. In Denmark, a context of labour shortage as well as the expectation of a short-lived crisis seem to have generated the perception that a more expansive response was unnecessary, while traditionally lower levels of spending and the resilience of a strong work-first orientation of public labour market policy in the UK made a more extensive contra-cyclical policy of this type seem unlikely and possibly - from the point of view of governments - undesirable. As the crisis developed, both countries then introduced fairly significant and aggressive cuts to labour market policies, with the aim of consolidating public finances. Neither the expansionary nor the austerity-driven phases of the crisis response saw significant changes in the distributive orientation of labour market policy in either country, and nor do policy developments since 2008 seem likely to change the direction of institutional developments underway in both Denmark and the UK since the mid-1990s, which have indeed continued during the crisis. The explicit targeting of labour market policies for cuts in the later phases of the crisis including, in Denmark, the main entitlement programme for the unemployed - may however carry the prospect of durably lower levels of investment in labour market policy in both countries in the future. 
A final distinctive response pattern is exemplified by the French and Spanish cases. Here the contra-cyclical labour market policy measures in response to the crisis were rather stronger and more extensive than in either Denmark or the UK, and unlike in Germany or the Czech Republic focused as much on outsiders as insiders. Furthermore, while governments in both countries have emphasised austerity measures since 2010, unlike elsewhere these have not to date resulted in any significant direct cuts to labour market policy expenditures. Perhaps more interestingly, in different ways in each country the crisis has tended to considerably accelerate, rather than to reverse or sideline, efforts to durably recalibrate labour market policies in favour of those with weaker labour market attachments. To cite but the most high profile examples, the successive reforms of employment protection pushed through first by the Zapatero and then Rajoy governments explicitly seek to reduce the regulatory dualism of the Spanish labour market, while the reform of French unemployment insurance in 2009 has recalibrated the system's operation in favour of those with more limited work records. In France, the period since 2008 has also seen an apparently more creative use of institutional resources by labour market policy actors, with the social partners and the state pooling contributory and fiscal resources to co-finance new measures for priority groups in a manner that has been highly unusual in French labour market policy to date (Clegg, 2011). In both cases the labour market policy response to the crisis thus seems to point to a step-change in both the pre-existinglogic of institutional development and in the distributive orientation of protection for workers. 



\section{Conclusion}

The economic crisis represents a major challenge for European labour market - and, more broadly, welfare state - policies. Unlike Vis et al. (2010), who admittedly focussed only on the early phases of the crisis, we find that in the field of labour market policy the crisis has generated distinctive policy responses across Europe. While all the countries we analysed expanded labour market policy efforts in the first phase of the crisis, these efforts differed in their extensiveness and in their distributive orientation. Subsequently, we have identified a bifurcation between states that have intensified structural reforms intended to reduce labour market segmentation, and those that have turned towards an aggressive, if more or less selective, retrenchment agenda.

Given that the latter is visible in countries as different as Denmark, Germany and the UK, it seems unlikely that welfare state traditions are sufficient to explain patterns of policy response (cf. Chung and Thewissen, 2011). We would tentatively suggest that the domination of particular combinations of interpretative frames for the economic crisis, and associated patterns of labour market policy response, can be explained with reference to the interaction between economic circumstances and the extent to which labour market policy paradigms were perceived by policy makers as 'settled' prior to the onset of the crisis. The relative importance of manufacturing in the Czech and German economies may help explain why expansionary measures focused so heavily on maintaining employment through protection of 'insiders' while measures for those most distant from the labour market bore the brunt of cuts, even though in the German case this pushed somewhat against the distributive logic of labour market reforms earlier in the decade. In Britain and Denmark, where in the 1990s and 2000s domestic policy-makers liked to talk up their labour market policy frameworks as models for other European countries, the need for either expansive measures or major changes of institutional and distributive orientation has seemed less pressing, leaving the route clear for an austerity discourse to play an increasingly important role in labour market policy debates. By contrast, in France and Spain labour market reform in general, and the reduction of insider-outsider dualism in particular, were widely perceived before the onset of the crisis as key to boosting economic growth potential, which perhaps helps understand why the crisis response in labour market policy has focused rather more than elsewhere on institutional and distributive recalibration. While it may have made decision making more difficult, the fact that in both these countries labour market policy is governed 
through complex interactions between national level bipartite dialogue and government decisions (Freyssinet, 2010) may also have helped to contribute to a more rounded labour market policy response to the crisis.

Rather than explaining cross-national diversity in policy responses, the main aim of this paper was instead to assess the longer-term implications of the economic crisis for labour market policy developments in Europe in the light of how governments have responded to this major shock. On this issue, the evidence provides grounds for both optimism and pessimism. On the one had, the recent crisis has stimulated no return to the 'labour shedding' policies of the 1980s, and nor have processes of distributive recalibration that have been underway in labour market policy been seriously challenged by policy responses adopted in most countries. Indeed, in some countries the prospects for the implementation of the latter agendas actually seems to have been improved by the crisis, which in places has deflected actors from policy routines, emboldened reformists and crystallised attention on the situation of those most precariously attached to the labour market. On the other hand, though, in a number of places the retrenchment of labour market policy has been brought firmly back onto the agenda by the crisis, including in the European country - Denmark - that had been most widely vaunted in the 2000s as a model for others to follow.

Of course, given the context of ongoing economic uncertainty, turmoil surrounding the future of the Euro and - at the time of writing - unemployment levels that are rising once again in many European countries, the question of the future of European labour market policies cannot be given a very definitive response. However, if it seems unlikely that the longer-term effects of the crisis which began in 2008 will be to wholly unravel the relative consensus that has built-up over the last 15 years around the centrality of effective and equitable labour market policies to a well-functioning social and economic model, there is a clear risk that the ongoing fiscal, debt and economic crisis may yet shift the centre of gravity of that consensus even further rightwards, leading to leaner and meaner labour market policy mixes in the coming years. 


\section{References}

Bogedan, C., Bremer, W. and Herzog-Stein, A. (2009) 'Betriebliche Beschäftigungssicherung in der Krise: Eine Kurzauswertung der WSI-Betriebsbefragung 2009', WSI-Report no 1, Düsseldorf: Institute of Economic and Social Research.

Boin, A., t’Hart, P. and McConnell, A. (2009) 'Crisis exploitation: political and policy impacts of framing contests', J ournal of European Public Policy 16, 81-106.

Bonoli, G. (2010) 'The political economy of active labour market policy', Politics \& Society, 40, 1, 435-457.

Castles, F. (2010) 'Black swans and elephants on the move: The impact of emergencies on the welfare state', J ournal of European Social Policy, 20, 2, 91-101.

Chung, H. and Thewissen, S. (2011) 'Falling back on old habits? A Comparison of the Social and Unemployment Crisis Reactive Policies in Germany, the UK, and Sweden', Social Policy \&Administration, 45, 4, 354- 370.

Clasen, J. (2005) Reforming European Welfare States: The UK and Germany compared, Oxford: Oxford University Press.

Clasen, J . (2009) 'The United Kingdom', in P. De Beer and T. Schils (eds), The Labour Market Triangle. Employment Protection, Unemployment Compensation and Activation in Europe, Cheltenham: Edward Elgar.

Clasen, J. (2011) 'The UK - towards a single working age benefit system', in J . Clasen and D. Clegg (eds) Regulating the Risk of Unemployment. National Adaptations to Post-Industrial Labour Markets in Europe, Oxford: Oxford University Press.

Clasen, J . and Clegg, D. (2011) 'The transformation of unemployment protection in Europe', in J. Clasen and D. Clegg (eds) Regulating the Risk of Unemployment. National Adaptations to Post-Industrial Labour Markets in Europe, Oxford: Oxford University Press.

Clasen, J. And Goerne, A. (2011) Exit Bismarck, enter dualism? Assessing contemporary German labour market policy', J ournal of Social Policy, 40, 4, 795-810.

Clasen, J . and Goerne, A. (2012) 'Germany: ambivalent activation', in I. Lødemel and A. Moreira (eds) Workfare Revisited, Oxford University Press (forthcoming).

Clegg, D. (2010) Labour market policy in the crisis: the UK in comparative perspective', J ournal of Poverty and Social J ustice, 18, 1, 5-17.

Clegg, D. (2011) 'France: integration versus dualisation', in Clasen, J. and Clegg, D. (eds.) Regulating the Risk of Unemployment. National Adapta- 
tions to Post-Industrial Labour Markets in Europe, Oxford: Oxford University Press.

Clegg, D. and Palier, B. (2012) 'Implementing a myth: work conditionality in French minimum income policy', in Lødemel, I. and Moreira, A. (eds.) Workfare Revisited, Oxford University Press (forthcoming).

Cornilleau, G. and Elbaum, M. (2009) 'Indemnisation du chômage: une occasion manquée face a la crise?', Lettre de l'OFCE, no. 307, February 2009.

DARES (2011) 'Les contrats d'aide à l'emploi en 2009', Analyses no. 018, March 2011, Paris: DARES.

Dingeldey, I. (2011) 'Germany: moving towards integration whilst maintaining segmentation', in J. Clasen and D. Clegg (eds) Regulating the Risk of Unemployment. National Adaptations to Post-Industrial Labour Markets in Europe, Oxford: Oxford University Press.

EIRO (2009) Spain: Green Light for New Unemployment Protection Measure, EIRO ES0909029I, http://www.eurofound.europa.eu/eiro/2009/09/ articles/es0909029i.htm, consulted 06/06/2011

EIRO (2010a) Czech Republic: New Government Wants to Reform Labour Code, EIRO CZ1007019I, http://www.eurofound.europa.eu/eiro/2010/07/ articles/cz1007019i.htm, consulted 24/03/11

EIRO (2010b) Spain: Government Endorses Plan to Cut Public Deficit, EIRO ES1006011I, http:// www.eurofound.europa.eu/eiro/2010/06/articles/ es1006011i.htm, consulted 06/06/2011

EIRO (2011a) Czech Republic: Amendments to Social and Labour Law Come into Force, EIRO CZ1102049I, http://www.eurofound.europa.eu/ eiro/2011/02/articles/cz1102049i.htm, consulted 07/06/2011

EIRO (2011b) Spain: Agreement Signed on Growth, Employment and Guaranteed Pensions, EIRO ES1102031I, http://www.eurofound.europa.eu/ eiro/2011/02/articles/es1102031i.htm, consulted 06/06/2011

European Commission (2010a) Industrial Relations in Europe 2010, DG Employment, Social Affairs and Inclusion, Luxembourg: Publications Office of the European Union.

European Commission (2010b) Employment in Europe 2010, DG Employment, Social Affairs and Inclusion, Luxembourg: Publications Office of the European Union.

European Employment Observatory (2010) European Employment Observatory Review Spring 2009, Luxembourg: Publications Office of the European Union.

Farnsworth, K. and Irving, Z. (2011) 'Varieties of crisis', in Farnsworth, K. and Irving, Z. (eds.) Social Policy in Challenging Times: Economic Crisis and Welfare Systems, Bristol: Policy Press.

Fender, V. (2010) 'The changing nature of the UK's trade deficits, 1985-2008', Economic \& Labour Market Review, 4, 1, 18-24.

Freyssinet, J. (2010) Tripartite Responses to the Economic Crisis in the Principal Western Democracies, ILO Dialogue working paper, no 12.

Freyssinet, J. (2011) 'Négociations interprofessionelles et crise économique', La Revue del'IRES, 69, 33-67.

Gautié, J. (2011) 'France: Protecting the insiders in the crisis and forgetting the outsiders?', in Vaughan-Whitehead, D. (ed.) Work Inequalities in the Crisis: Evidence from Europe, Geneva, ILO. 
Goul-Andersen, J . (2011) 'Denmark - ambiguous modernisation of an inclusive unemployment protection system', in Clasen, J. and Clegg, D. (eds.) Regulating the Risk of Unemployment: National Adaptations to Post-Industrial Labour Markets in Europe; Oxford: Oxford University Press.

Heclo, H. (1974) Modern Social Politics in Britain and Sweden: From Relief to Income Maintenance, New Haven, Yale University Press.

Hijzen, A. and D. Venn (2011), The Role of Short-Time Work Schemes during the 2008-09 Recession, OECD Social, Employment and Migration Working Papers, No. 115, Paris: OECD.

ILO (2010) 'France's response to the crisis', ILO G20 Country Briefs, Geneva: ILO.

Kingdon, J . (1995) Agendas, Alternatives and Public Policy, New York: Harper Collins.

Kuipers, S. (2006) The Crisis Imperative: Crisis Rhetoric and Welfare State Reform in Belgium and the Netherlands in the Early 1990s, Amsterdam: Amsterdam University Press.

Kvist, J. and I. Harsløf (2011) The Nordic approach combining minimum security with activation: From workfare with welfare to instigating dual tracks based on ethnicity in Denmark, Paper presented at the conference Anti-Poverty Programs in a Global Perspective, WZB, Berlin, 20-21 J une 2011.

Leschke, J. and Watt, A. (2010) How do institutions affect the labour market adjustment to the economic crisis in different EU countries?', ETUI Working Paper 2010.04, Brussels: ETUI.

Leschke, J., Theodoropoulou, S. and Watt, A. (2012) How do economic governance reforms and austerity affect inclusive growth as formulated in the Europe 2020 strategy?', in Lehndorff, S. (ed.) A Triumph of Failed Ideas: European Models of Capitalism in the Crisis, Brussels: ETUI.

Möller, J. (2010) The German labor market response in the world recession - de-mystifying a miracle, Zeitschrift für Arbeitsmarktforschung, 42, 325336.

OECD (2010a) 'Economic Survey of the Czech Republic 2010', OECD Policy Brief, April 2010, Paris: OECD.

OECD (2010b) Employment Outlook 2010, Paris: OECD.

OECD (2011a) Employment Outlook 2011, Paris: OECD.

OECD (2011b) OECD. StatExtracts, Paris: OECD.

Rueda, D. (2007) Social Democracy Inside-Out: Partisanship and Labor Market Policy in Industrialized Democracies, Oxford, Oxford University Press.

Sirovatka, T. And Hora, O. (2011) 'Czech Republic: diversification, activation and marginalization', in Clasen, J . and Clegg, D. (eds.) Regulating the Risk of Unemployment. National Adaptations to Post-Industrial Labour Markets in Europe; Oxford: Oxford University Press.

Svallfors, S. (2010) 'Public attitudes', in Castles, F. et al. (eds.) The Oxford Handbook of the Welfare State, Oxford, Oxford University Press.

Taylor-Gooby, P. And Stoker, G. (2011) "The Coalition programme: a new vision for Britain or politics as usual?', The Political Quarterly, 82, 1, 4-15.

Viebrock, E. and Clasen, J. (2009) 'Flexicurity and welfare reform: A review', Socio-Economic Review, 7, 305-331. 
Vis, B., van Kersbergen, K. and Hylands, T. (2010) Did the financial crisis open up opportunities for welfare state reform?, paper prepared for the 'International Political Economy' workshop, Dutch/Flemish Politicologenetmaal, Leuven 27/28 May 2010.

Wölfl, A. and Mora-Sanguinetti, J. (2011) Reforming the labour market in Spain, OECD Economics Department Working Paper, no. 845, Paris: OECD. 
European

Trade Union Institute

Bd du Roi Albert II, 5

1210 Brussels

Belgium

Tel.: +32 (0)2 2240470

Fax: +32 (0)2 2240502

etui@etui.org

www.etui.org 